\title{
ПРОИЗВОДНОЕ 2-АМИНОБЕНЗИМИДАЗОЛА - НОВОЕ ЦИТОПРОТЕКТОРНОЕ СОЕДИНЕНИЕ
}

\author{
В.Ю. Муравьева', Н.А. Гурова', О.Н. Жуковская², А.С. Тимофеева' \\ ${ }^{1}$ Волгоградский Государственный Медицинский Университет Минздрава РФ, \\ 400131, Россия, г. Волгоград, пл. Павших Борцов, 1. \\ ${ }^{2}$ НИИ ФОХ ЮФУ, Россия, 344090, Ростов-на-Дону, Стачки, 194/2.
}

DOI: 10.19163/MedChemRussia2021-2021-94

E-mail:w_fedorchuk@mail.ru

Одной из мишеней для патогенетической коррекции ишемического и реперфузионного повреждения сердца и мозга может выступать $\mathrm{Na}^{+} / \mathrm{H}^{+}$обменник 1 изоформы (NHE-1). На основании анализа литературы, собственных исследований invitro и методов insilico было выявлено, что высокая NHE-1 ингибирующая активность наиболее характерна для производных 2-аминобензимидазола и определяется электронными параметрами центрированными на гуанидиновый фрагмент соединений с частично встроенной в цикл гуанидинновой группой. Соединение РУ-1355 \{хлорид 2-амино-3-[2-(4-фторфенил)2-оксоэтил]-1-[2-(морфолино) этил]-1Н-бензимидазолия\}, синтезированного в НИИ ФОХ ЮФУ, оказывает NHE-1-ингибирующую активность на тромбоцитах кролика (IC $\left.\mathrm{C}_{50}=5,42 \times 10^{-10} \mathrm{M}\right)$, превосходя по терапевтическому индексу препарата сравнения зонипорид в 6 раз. На моделях постреперфузионных повреждений миокарда и мозга invivoизучаемое веществооказало цитопротекторное действие, улучшало гемореологические свойства крови. Данная молекула рассматривается как перспективная для предотвращения развитию «кальциевого» парадокса» и реализации адекватной цитопротекции.

Схема синтеза

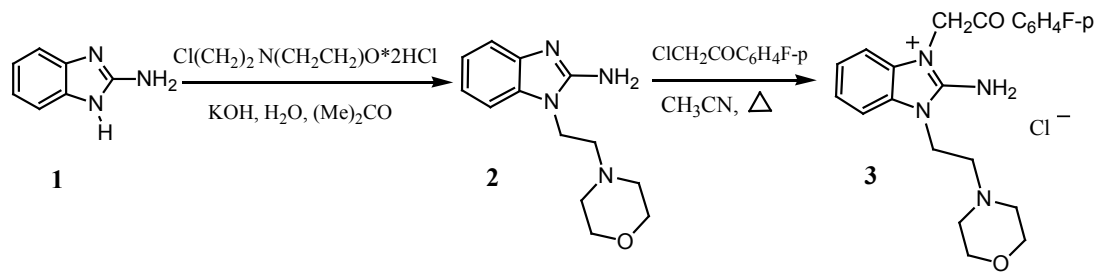

Исходный амин 2 получали алкилированием 2-аминобензимидазола (1) в двухфазной системе ацетон-50\% раствор КОНс выходом 95-96\%. Далее при кватернизации амина 2 $\omega$-хлор-4-фторацетофеноном синтезировано соединение 3 (РУ-1355) с выходом 93\%.

Разработка метода синтеза Ру-1355 выполнена при финансовой поддержке Министерства науки и высшего образования РФ, грант FENW-2020-0031 (0852-2020-0031). 